\title{
Developing the Green Building Materials Selection Criteria for Sustainable Building Projects
}

\author{
Ezzaddin Abdullah Al-Atesh ${ }^{\mathrm{a}, *}$, Yani Rahmawati ${ }^{\mathrm{b}}$, Noor Amila Wan Abdullah Zawawic, Ali Elmansoury ${ }^{\mathrm{d}}$ \\ ${ }^{a}$ Department of Civil \& Environmental Engineering, Universiti Teknologi PETRONAS, 32610 Seri Iskandar, Perak, Malaysia \\ ${ }^{b}$ Architectural Engingeering, Universitas Gadjah Mada, 55281 Yogyakarta, Indonesia \\ ${ }^{c}$ Institute of Self Sustainable Building, Universiti Teknologi PETRONAS, 32610 Seri Iskandar, Perak, Malaysia \\ ${ }^{d}$ Architectural Department, College of Engineering, Al-Azhar University, Egypt \\ Corresponding author: "ezzaddin_19001251@utp.edu.my; alatesh9@gmail.com
}

\begin{abstract}
The utilization of green building materials (GBMs) becomes necessary. The lack of clear guidelines on utilizing GBMs and difficulties in adjusting GBMs criteria adequately for the three sustainability pillars is a major obstacle. Furthermore, it is an issue of multi-criteria decision that considers all sustainability factors during the selection process and implies multi-criteria decision-making mechanism statistical techniques. Consequently, the main challenge is identifying assessment criteria based on the sustainability concept and prioritizing and consolidating the evaluation framework of relevant criteria. Therefore, this paper aims to determine the selection of GBMs criteria to achieve sustainable building projects in Malaysia. To do so, a total of three key criteria and 32 sub-criteria were identified by a review of the previous literature, accompanied by a semi-structured interview with 12 experts. Data were obtained using a questionnaire from 73 building professionals when exploring the country's GBM criteria using the Exploratory Factor Analysis (EFA). The findings indicate that the associations between these criteria across the EFA have three key components: environmental, economic, and social. A mean and standard deviation scatter plot analysis was also performed to evaluate the data descriptively to define the relevance criteria. Finally, this study strengthens the current management of building engineering by enhancing the criteria for selecting GBMs in the Malaysian construction industry to satisfy the sustainability objectives of the building projects.
\end{abstract}

Keywords - Material selection; Green Building Materials (GBMs) assessment; building industry; Malaysia; exploratory factor analysis.

\section{INTRODUCTION}

The building industry has a significant influence over all the life cycles of the environment, economy, and society in developed and developing countries [1]. The building industry is one of the largest operating sectors in many countries [2]. Building projects demand over $40 \%$ of global energy and contribute an average of $1 / 3$ of overall GHG emissions [3]. Construction is anticipated to double its emissions by 2050 . This industry is committed to enhancing resource use by developing architecture to mitigate environmental implications across buildings worldwide [4]. Many governments recognize this as one way of resolving problems of sustainability [5]. This has contributed to create "sustainable buildings" that make their construction processes environmentally friendly and resource-efficient [6]. The sustainable building strategy has tremendous potential for a significant contribution to sustainable development (SD) regarding the building industry with such a growing impact.

The policymakers of the industry are now making sustainable development a significant target [7]. SD has been described as an approach that addresses the demands of current generations without affecting future generations' needs. The SD is currently under debate and discussion in government, NGO, research, and concentration levels leading to environmental, economic, and social agendas at the national and international level [8]. Thus, without sacrificing future generations and their ability to meet their own needs, $\mathrm{SD}$ can be seen as a solution to current requirements. Sustainability means the triple bottom line (TBL) of the organization [9], which referred to the three dimensions of sustainability environment, economic and social [10]. The intensity of efforts to achieve sustainable development depends on decision-making by various building companies: clients/ developers, consultants, contractors, etc. 
In Malaysia, construction practices were enormously expanded. The government is making efforts to establish a sustainable approach through the Malaysian Government Initiative to enhance sustainability to achieve the built environment [11]. The best way to start integrating sustainability concepts into building projects has been by carefully selecting green building materials (GBMs). Meanwhile, there is a lake of criteria that lead to the selection process of green building materials [12]. Therefore, building stakeholders are facing a challenge in choosing green building materials [13]. The sustainability of materials selection for building projects is an important decision [14]. Building materials selection is a multi-criteria decision-making, dependent on trusting experienced stakeholders rather than applying the numerical approach due to insufficient availability and formal measurement criteria [15]. As it is understood in practice that overlap can exist, the selection of GBMs assessment criteria should be considered in detail at the design stage [8].

Therefore, for the design team members to choose the right sustainable materials for the building projects, it is vital to develop and prioritize a comprehensive and systematic sustainable materials process to define and prioritize specific green building materials criteria. Hence, the present study aims to explore the criteria for GBMs through an extensive literature review. An EFA analysis and ranking of the relative importance of the GBM parameters follow previous studies and a panel of experts. This study's meaningful criteria would enable sustainability principles to be incorporated into the decision-making process to select GBMs in building projects. Subsequently, the enhancement and efficiency of the sustainable building industry will be increased. This study would help decision-makers to achieve green building projects by enhancing their selection of the used materials. This study is vital for the Malaysian building industry and developing nations [16].

\section{MATERIALS AND METHOD}

This paper aims to improve the sustainable delivery of building projects in the Malaysian construction industry by implementing sustainable criteria for the development of GBMs. Fig. 1, adopted from Buniya et al. [17], and Othman, et al. [18] show the study's research stages.

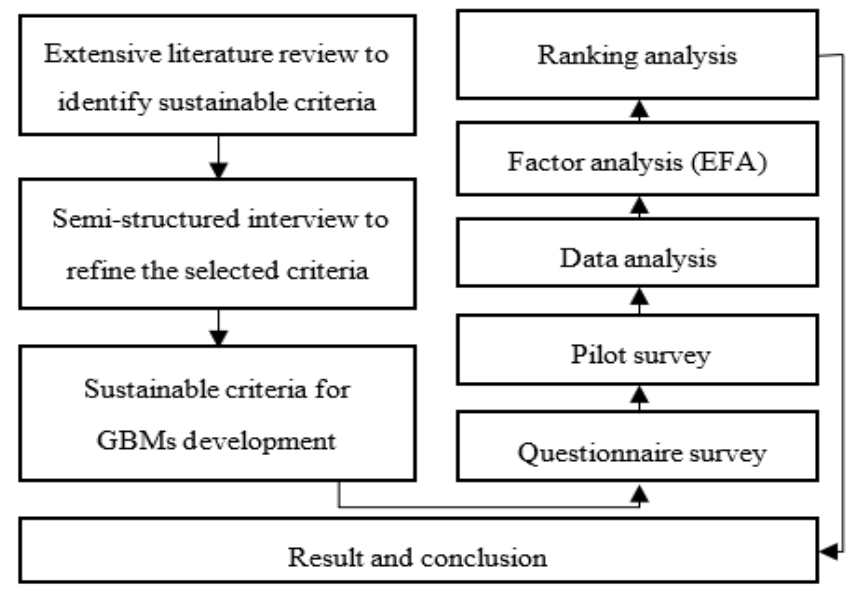

Fig. 1 Research framework
The study followed exploratory sequential mixed-method analysis. Mixed method research is relevant, as no clear approach is suitable for all analyses [19]. It is verified that mixed approaches to investigate the same problem will help find certain repeated trends or consistent associations among variables [6]. Consequently, this study was conducted through extensive literature review related to sustainability and expert's opinion; however, the current study's emphasis for the quantitative stage was designed to gather views from industrial practitioners via questionnaire surveys.

\section{A. Investigating Sustainability Criteria (Previous Studies)}

Sustainability refers to improving the quality of life and enabling people to live in a healthier world to improve current and future generations' natural, social and economic situations [20]. At the first sustainable development international conference in Tampa, the first concept of sustainability was proposed. Sustainable management is defined as a safe building environment based on resource-efficient and ecological values [8]. The rapid growth of several cities has led to high demand for residential and commercial buildings [17]. It needs many resources to tackle urbanization's rapid growth, but resource consumption will make it exhausted [10].

The Sustainable Development Goals for 2030 have been established to transform our planet by resolving complex threats to the world's health, environmental and economic stability [21]. With 17 targets and 169 objectives, sustainable cities and municipalities are essential SDGs to overcome different complex human challenges [22]. Building companies worldwide are moving towards sustainability daily due to their understanding of the depletion growing of natural resources, health in the world, and the market demand for sustainable materials. Malaysia's construction industry plays a significant part in the Malaysian economy, contributing approximately 3 to 5 percent to the annual Gross Domestic Product (GDP) [13]. Considering the massive emissions of $\mathrm{CO} 2$ from inappropriate materials and energy consumption by materials, buildings, and construction environment management are essential [23]. In conditions of climate change, these materials do not remain stable. Inadequate material selection would reduce the acceptability of social buildings. The local community should approve the chosen materials and the political risks considered. Besides, the economic relationship with the environment and community often indirectly reduces the environmental effect on society by selecting suitable materials [8].

The selection of materials is indeed very significant for the building industry's design, development, and sustainability [24]. Many studies have researched sustainability in terms of selecting building materials [25]. As mentioned in the previous section, criteria for selecting materials in the building industry are based on the three principal environmental, economic, and social sustainability pillars collectively known as TBL [26]. With the use of environmentally friendly materials, green building goes back to the old days. However, during the energy crisis, the official green building program began, and the concept of sustainable construction was discussed and spread in the sixties and seventies [27]. Green building materials that can efficiently mitigate the environment and harm to human health across the 
entire life cycle are considered ecological, health promotion, recycled, or high-efficient construction materials [28]. GBMs provides a growing assortment of currently available products and materials for buildings, furnishings, and energy plants. Many researchers have examined building materials selection in sustainability pillars and have defined a few subsustainable criteria under the main sustainable environmental, economic, and social criteria. The choice of green materials leads to sustainable development, which covers all three sustainability pillars [25].

The assessment of construction materials should be carried out against practical criteria of environmental, economic, and social. Combining all criteria offers a general image of materials and helps with a multi-criteria approach to choosing appropriate buildings. A comprehensive list of criteria focused on sustainability pillars and the needs of various project participants should be drawn up to capture the potential value of buildings better and encourage sustainable growth of building environments. A systematic literature review was performed and checked by experts in order to choose GBM criteria. Table I identified the sustainable criteria for GBMs selection from previous studies.

TABLE I

SustainABLE CRITERIA FOR GREEN BuILding MATERIALS SELECTION

\begin{tabular}{|c|c|c|}
\hline Codes & Environmental criteria & Studies \\
\hline E1 & Recycling and reuse possibilities & $\begin{array}{l}{[10],[29]} \\
{[30]}\end{array}$ \\
\hline E2 & Options for environmentally safe disposal & {$[29]$} \\
\hline E3 & Effects of air quality content & [31] \\
\hline E4 & Healthy interior environment & {$[25]$} \\
\hline E5 & $\begin{array}{l}\text { Environmental form (Eco } \\
\text { environmentally) }\end{array}$ & [32] \\
\hline E6 & Embodied energy within a material & {$[33]$} \\
\hline E7 & Water consumption & {$[10,25]$} \\
\hline E8 & Waste management & {$[8,34]$} \\
\hline E9 & Land acquisition & {$[10]$} \\
\hline E10 & Production and transportation activities & {$[10,35]$} \\
\hline E11 & Consumption of natural resources & {$[35]$} \\
\hline Codes & Economic criteria & Studies \\
\hline EC1 & Energy efficiency & {$[25]$} \\
\hline $\mathrm{EC} 2$ & Investment cost & {$[36]$} \\
\hline $\mathrm{EC} 3$ & Operation and maintenance cost & {$[36,37]$} \\
\hline $\mathrm{EC} 4$ & Building material social costs & {$[10]$} \\
\hline EC5 & Meet the needs of stakeholders & {$[10,38]$} \\
\hline EC6 & Financial and economic risks & {$[36]$} \\
\hline $\mathrm{EC7}$ & Contribution to taxation & {$[25,34,39]$} \\
\hline EC8 & The life expectancy of the material & {$[19,37]$} \\
\hline Codes & Social criteria & Studies \\
\hline $\mathrm{S} 1$ & Ecological and social acceptability & {$[32]$} \\
\hline $\mathrm{S} 2$ & Social advantage and growth & {$[36]$} \\
\hline $\mathrm{S} 3$ & Availability and adaptation & {$[38]$} \\
\hline $\mathrm{S} 4$ & Health and safety & {$[10,31]$} \\
\hline S5 & Risks to policy & {$[36]$} \\
\hline S6 & Aesthetics & {$[10,40]$} \\
\hline S7 & $\begin{array}{l}\text { Natural pollution tolerance and habitat } \\
\text { catastrophes }\end{array}$ & {$[25,31]$} \\
\hline $\mathrm{S} 8$ & Local use of material & {$[25,41]$} \\
\hline S9 & Labor availability & {$[42]$} \\
\hline S10 & Fire resistance & [31] \\
\hline S11 & Ease of Construction (buildability) & [19] \\
\hline S12 & Isolation of noise pollution & \\
\hline $\mathrm{S} 13$ & $\begin{array}{l}\text { Ease and ability to integrate with other } \\
\text { materials }\end{array}$ & {$[12]$} \\
\hline
\end{tabular}

\section{B. Qualitative Study (Semi-Structured Interview)}

Sustainability criteria measurements are taken from various studies concerned with developing sustainable criteria in the building industry. Following this, a qualitative method by 12 semi-structured interviews with industry experts was arranged to understand the sustainability requirements that could affect sustainable criteria in building projects through a "purpose sampling" approach [43], [44]. This method helps researchers accomplish research goals and monitor the degree of difference among interviewees [45]. Even though 12 interviews can tend to be moderate samples, Mason [46] reports that the sample size is essential to qualitative analysis because its importance is dependent on the accuracy of the results.

"Considering the different positions played in building projects, the interviewed profiles testify that the various organizations contribute to the study" [18]. Besides, equal representation of associations is offered for different construction activities. It was expected that such a skilled pool would have the breadth of expertise and experience available and healthy differences to measure dramatically [47]. Consequently, sustainable criteria that have been identified from the previous study based on the three principal environmental, economic, and social sustainability pillars collectively known as TBL [26] have been refined and modified based on the interview discussion. It was agreed that each main component for these criteria was identified from the previous studies (Environmental, Economic, and Social). However, the interviews eliminated three criteria, added two and made some minor modifications.

\section{Quantitative Study (Questionnaire survey)}

To verify the sustainable criteria scales derived from previous studies and the semi-structured interview, a questionnaire sample was adopted to analyze these phases and their destinations using an EFA analysis [48]. In support of the development of the questionnaire, the exhaustive literature review showed no complete list covered assessment criteria, specifically for selecting green building materials (GBMs) development, which covers the principles of sustainability. The literature review compiled a tentative collection of GBMs requirements and included them in the pre-test questionnaire. A pilot study was subsequently performed with Twelve experts in selecting GBMs to validate the questionnaire [49]. Experts have been asked to evaluate all questions' exhaustiveness and verify the adequacy and appropriateness of sustainable criteria contained in the pretested questionnaire, particularly in the Malaysian context.

The experts omitted unnecessary criteria and added criteria that were perceived to the subject. Findings from the literature review, semi-structured interview, and the pilot study test, 29 sustainable criteria for GBMs selection in the building industry were identified in Table I. There were three sections of the final version of the questionnaire. The first section gathered background/demographic information for respondents and the degree of understanding of the GBMs, and the frequency of involvement in GBMs selection. The second part focused on assessing the importance of the 29 criteria under the categorizations (environmental, economic, and social sustainability). The third part of the questionnaire is an open-ended question to encourage the respondents to 
provide any supplementary criteria that could influence the selection of GBMs, but not included in the questionnaire provided. A five-point Likert scale $(1=$ least agree to $5=$ extremely agree) is used to rate GBMs criteria, widely used in various previous studies [1], [5], [50].

\section{Data Collection}

The survey's targeted respondents were the professionals involved in GBMs selection, such as contractors, designers, architects, consultants, and clients. This research employed a convenience method of sampling. To obtain accurate and adequate data collected, the survey respondents must include various stakeholders to ensure a homogeneous and sufficient population sample. The questionnaires were subsequently distributed to various companies in the Malaysian building industry. In February 2020, a total of 210 surveys were distributed. A reminder was sent to complete the questionnaire to increase the response rate. A total of 79 questionnaires was returned accordingly after excluding the invalid responses. The analysis was then based on 73 valid responses, which showed a $34.8 \%$ response rate. Therefore, the response rate was accepted according to most questionnaire surveys in the construction industry, agreed at a standard rate between $20 \%$ and $30 \%$ [51].

\section{E. Data Analysis Method}

The valid data obtained were analyzed using the Statistical Package for Social Sciences (SPSS version 25) and Microsoft Excel software. First, the validity test was conducted using the Kaiser method. By this method, there is a value called eigenvalue, which should be greater than 1 . The equivalent value below 1 is inadequate and, therefore, inappropriate for factor analysis [52]. The varimax rotation method was applied after the primary factor analysis to determine the linear combination of the original factors so that the variance of the loading is maximized. However, the reliability rating scale (15) was examined using Cronbach's coefficient alpha. The range of $\alpha$ value for Cronbach is from 0 to 1 , and the higher value gives a higher degree of internal consistency. Finally, a ranking analysis was performed using a scatter plot of mean and standard deviation scores to determine the importance of GBMs criteria for materials selection [53].

\section{RESULTS AND DISCUSSIONS}

\section{A. Profiles of Respondents}

The collected data from the questionnaire survey of this study showed that the highest number of respondents are with years of experience between 5 and 10 years is $27.4 \%$, followed by those with years of experience between 10 and 15 years is $26.0 \%$, and the lowest of respondents is $12.3 \%$ with less than five years of experience. According to respondents' professional field, architects and geotechnical engineers have the highest percentage were observed with $46.6 \%$ and $30.1 \%$, respectively, as illustrated in Fig. 2. Concerning the current position, directors, senior managers, managers, design engineers, and site engineers account for $8.2 \%, 24.7 \%, 35.6 \%, 15.1 \%$, and $16.4 \%$, respectively.

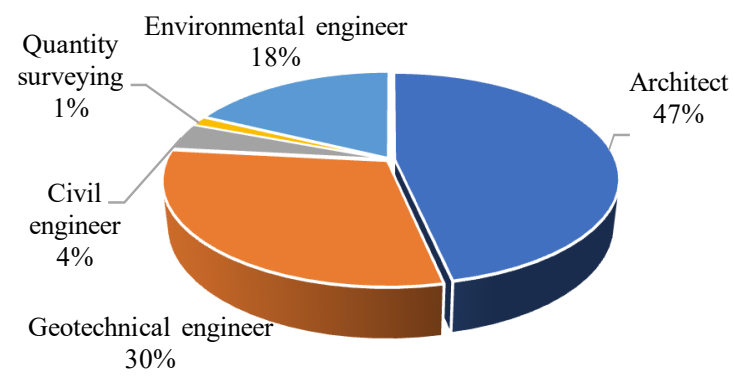

Fig. 2 The professional field of respondents

The questionnaire surveys were received from clients/ developers $30.1 \%$, consultants $37.0 \%$, and contractors $32.9 \%$. Moreover, most of the respondents are aware of GBMs selection, as shown in Fig. 3. It can be concluded from the respondents' profile that the respondents are very experienced and played an essential role in GBMs selection. Therefore, the view of these experts is essential and dependable on evaluating the GBMs criteria.
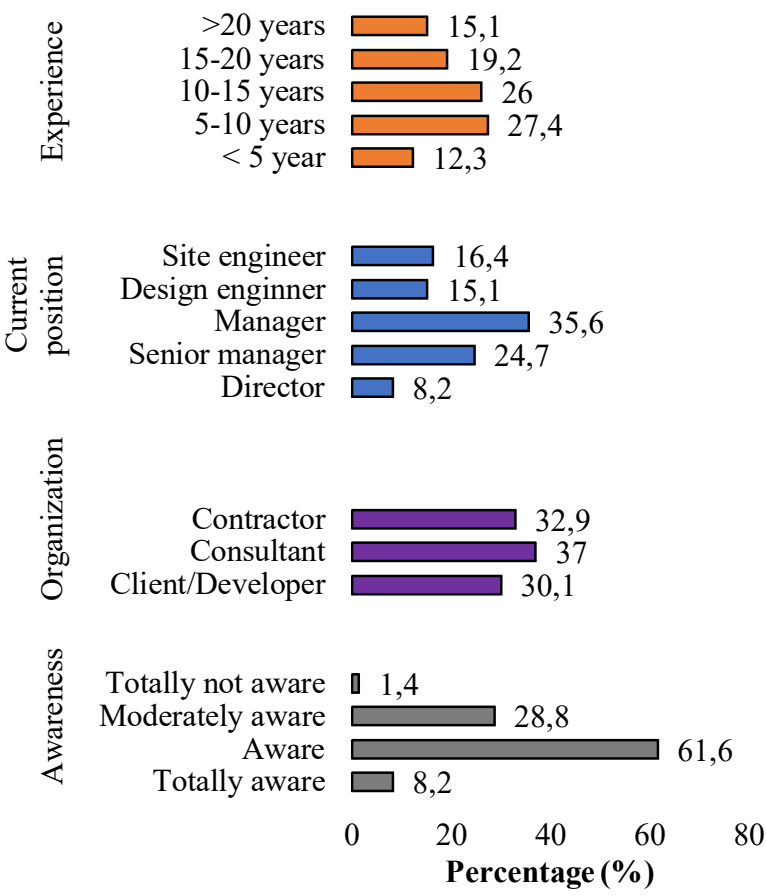

Fig. 3 Profile of respondents

\section{B. EFA for Sustainable Criteria}

Following the interview with experts, EFA analysis was conducted to check the themes, and it is measurements obtained from the literature review and the interview sessions. Factor analysis was used to analyze the interrelation structure between the criteria. The factor analysis was carried out using SPSS version 25. It is carried out in two stages: factor extraction and factor rotation.

A validity test is performed according to Kaiser's method before factor analysis. In this method, an eigenvalue below one is considered insufficient and unacceptable for the factor analysis. The survey data's appropriateness was assessed in the Kaiser-Meyer-Olkin (KMO) and the Bartlett sphericity test. The value above 0.5 on the KMO index and the sphericity 
check of Bartlett where $(\mathrm{p}<0.05)$ suggest the adequacy for factor analysis of the data set [19]. The correlation matrix was first examined in the factor analysis to determine the correlation among the criteria. If any of the variables had enormous correlations or cross-loading, they were ruled out. The results analyzed shown that the KMO sample adequacy value was 0.828 , higher than 0.5 . The Bartlett sphericity test and the associated significance level were 8431,239 and 0,000, respectively.

The interactions are referred to as group loadings. The more latent variable contributes, the higher value of absolute loading. The components extraction was based on the total variance, which indicated eigenvalues of 1 and more. Therefore, three components explain a total variance of $84.76 \%$. Table II presents the factor loading of each variable in the rotated component matrix. However, the coefficient of reliability also analyzed, and it is usually varying from 0 to 1 .

TABLE II

FACTOR LOADING OF GBMS CRITERIA

\begin{tabular}{|c|c|c|c|}
\hline \multirow{2}{*}{ Variable } & \multicolumn{3}{|c|}{ Components } \\
\hline & Economic & Social & Environmental \\
\hline E2 & & & 0.842 \\
\hline E6 & & & 0.814 \\
\hline E3 & & & 0.810 \\
\hline E8 & & & 0.656 \\
\hline E9 & & & 0.851 \\
\hline E1 & & & 0.849 \\
\hline E4 & & & 0.792 \\
\hline E5 & & & 0.745 \\
\hline E7 & & & 0.832 \\
\hline EC6 & 0.869 & & \\
\hline EC4 & 0.806 & & \\
\hline $\mathrm{EC} 3$ & 0.696 & & \\
\hline $\mathrm{EC} 2$ & 0.677 & & \\
\hline EC5 & 0.906 & & \\
\hline EC8 & 0.833 & & \\
\hline $\mathrm{EC7}$ & 0.857 & & \\
\hline S6 & & 0.839 & \\
\hline S10 & & 0.779 & \\
\hline $\mathrm{S} 3$ & & 0.816 & \\
\hline $\mathrm{S} 11$ & & 0.702 & \\
\hline $\mathrm{S} 12$ & & 0.653 & \\
\hline S5 & & 0.847 & \\
\hline S8 & & 0.794 & \\
\hline S4 & & 0.792 & \\
\hline $\mathrm{S} 1$ & & 0.785 & \\
\hline $\mathrm{S} 2$ & & 0.683 & \\
\hline S9 & & 0.752 & \\
\hline
\end{tabular}

The internal consistency of reliability for the criteria is more excellent on the scale parameter when the $\alpha$ value is closer to one. The $\alpha$ value 0.7 is the acceptable lower limit [54]. Cronbach's $\alpha$ values for the criteria of environmental, economic, social, and all are 0.889, 0.877, 0.928, 0.957, respectively. The conclusion that all $\alpha$ values are acceptable and the scale of the internal consistency criteria is excellent. Overall, the result from the EFA analysis shows that a total of three latent groups have been extracted to present the GBMs criteria. The following parts discussed the descriptions of these latent factors.

1) Environmental Criteria: The first component presented the variable directly contributing to the "Environmental", such as the impact of materials on air quality, healthy interior environment, waste management, and production and transportation activities. The building industry has a massive effect on our environment [8]. Since building materials contribute to the environmental impacts, the consideration of environmental criteria has become significant.

The building industry is struggling to adopt sustainable practices and seeking new strategies [10]. Environmental criteria are important to support design decisions and choices of the right materials and should complement overall strategic sustainability goals. Depending on the environmental criteria established for material selection, the sustainability of a building can be achieved. However, suitable natural resources and raw materials would be useful to achieve the environmental goals [54]. The building industry is recognized as one of the most consumers of energy and therefore creates tremendous environmental pressures [4].

Furthermore, it noted that specific resources are minimal, and residual stocks should be carefully handled [55]. The building industry is considered one of the major consumers of natural resources. Therefore, sustainable buildings significantly reduce the contribution of the excessive use of natural resources and raw materials.

2) Economic Criteria: The second component presented the variable directly contributing to the "Economic". Therefore, this latent group presented variables such as operation and maintenance cost, financials and economic risks, the societal cost of materials, and investment cost, which support stakeholders in the decision making during the selection of the materials with consideration of the concept of life cycle cost and the project's budget. Stakeholders concentrate on the early recognition of the building projects' financial sustainability due to the rising to produce environmentally friendly buildings. Enhancing the cost efficiency of buildings is considered a significant interest to all stakeholders [56].

The sustainability principle for the building industry aims to encourage maximum productivity with less financial costs [57]. The budget for construction projects is considered a significant parameter [58]. However, it is important to note that the quality of life is a primary concern of the green building assessment, leading to sustainable economic developments [59]. The definitions of life quality described by positive links to nature are comfort and convenience. Subsequently, to meet the sustainable economic, the life quality of materials should be considered. Meeting stakeholders' needs and life expectancy of materials are the variables listed under this component.

3) Social Criteria: The "Social" component is associated with ease and ability to integrate with other materials, resistance against natural contamination and habitat disasters, isolation of noise pollution, and ease of construction. The quest for equilibrium that meets several performance goals is one aspect of building design. The performance definition offers a logical framework for planning, constructing, dynamic, and adaptable to developments and changes [36]. A structure that does not recognize the importance of system interface and performance capability could result in an incompatibility system, malfunctions, and obsolescent risk. 
The maintenance and risks of a possible decline in the income are arising from the loss of tenants, which adversely affect the building's financial viability [37]. Therefore, it is significant to consider the performance requirements for building materials. Identifying performance criteria during the selection of the materials leads stakeholders to meet the target of performance capability.

Furthermore, consideration of social benefits during the selection of the materials is significantly essential. Social aspects are different tools in achieving sustainable building projects. A different value must be considered for supporting the use of local materials. Applying the health and safety of buildings helps to meet sustainability, which reduces injuries and accidents during and after the construction process, resulting in the reduction of insurance premiums of construction companies [60]. Hence, social benefits criteria take a place to achieve buildings sustainability.

\section{Ranking the Importance of GBMs Criteria}

After exploring the GBMs criteria for materials selection by EFA analysis, ranking analysis has been performed to assess the relative importance of these criteria based on survey results. The criteria were ranked according to their relative importance using a scatter plot of mean and standard deviation scores [53]. The statistical means, standards deviations, and ranks of the mentioned criteria are presented in Table III.

TABLE III

FACTOR LOADING OF GBMS CRITERIA

\begin{tabular}{|c|c|c|c|c|}
\hline \multirow[b]{2}{*}{ Criteria } & \multicolumn{4}{|c|}{ Analysis of mean and standard deviation scores } \\
\hline & Mean & SD & $\begin{array}{c}\text { Ranking by } \\
\text { category }\end{array}$ & $\begin{array}{l}\text { Overall } \\
\text { ranking }\end{array}$ \\
\hline \multicolumn{5}{|c|}{ Environmental criteria } \\
\hline E6 & 3.890 & 0.774 & 1 & 1 \\
\hline E5 & 3.795 & 0.865 & 2 & 7 \\
\hline E1 & 3.918 & 0.878 & 3 & 9 \\
\hline E8 & 3.493 & 0.884 & 4 & 10 \\
\hline E2 & 3.589 & 0.925 & 5 & 14 \\
\hline E7 & 3.507 & 0.945 & 6 & 21 \\
\hline E3 & 3.699 & 1.023 & 7 & 26 \\
\hline E4 & 3.438 & 1.054 & 8 & 27 \\
\hline E9 & 3.781 & 1.096 & 9 & 29 \\
\hline \multicolumn{5}{|c|}{ Economic criteria } \\
\hline EC8 & 3.890 & 0.792 & 1 & 2 \\
\hline EC5 & 4.288 & 0.823 & 2 & 4 \\
\hline EC3 & 3.603 & 0.829 & 3 & 5 \\
\hline $\mathrm{EC} 2$ & 3.671 & 0.851 & 4 & 6 \\
\hline EC7 & 3.904 & 0.900 & 5 & 12 \\
\hline EC1 & 3.603 & 0.909 & 6 & 13 \\
\hline $\mathrm{EC} 4$ & 4.014 & 0.935 & 7 & 18 \\
\hline EC6 & 4.205 & 0.942 & 8 & 19 \\
\hline \multicolumn{5}{|c|}{ Social criteria } \\
\hline $\mathrm{S} 4$ & 3.740 & 0.800 & 1 & 3 \\
\hline S7 & 3.616 & 0.876 & 2 & 8 \\
\hline S8 & 3.658 & 0.885 & 3 & 11 \\
\hline $\mathrm{S} 1$ & 3.671 & 0.929 & 4 & 15 \\
\hline S12 & 3.548 & 0.929 & 5 & 16 \\
\hline S5 & 3.726 & 0.932 & 6 & 17 \\
\hline S9 & 3.548 & 0.943 & 7 & 20 \\
\hline $\mathrm{S} 10$ & 3.356 & 0.948 & 8 & 22 \\
\hline S6 & 3.507 & 0.959 & 9 & 23 \\
\hline S3 & 3.699 & 0.982 & 10 & 24 \\
\hline S11 & 3.315 & 0.998 & 11 & 25 \\
\hline $\mathrm{S} 2$ & 3.658 & 1.083 & 12 & 28 \\
\hline
\end{tabular}

The degree of agreement between the respondents on the parameters is the standard deviation, while the relative value of others is the average [61]. The standard deviation values of the sustainable criteria of the GBMs are less than or around one, which indicates some consensus among the respondents.

Considering the environmental criteria, the results are as follows: $\mathrm{E} 6>\mathrm{E} 5>\mathrm{E} 1>\mathrm{E} 8>\mathrm{E} 2>\mathrm{E} 7>\mathrm{E} 3>\mathrm{E} 4>\mathrm{E} 9$. Waste management was ranked as the top priority, and it was also the highest among all criteria. Fatimah et al. [62] mentioned that the companies promote waste management and environmental actions as major actions for materials selection. This was followed by water consumption and the potential for recycling and reuse, respectively.

Krauklis et al. [63] agreed that recycling and reuse materials positively contribute to resource efficiency. Lam et al. [64] stated that negative effects on the climate have been central to climate change since the past decade. Environmental resources are enormously consumed to meet the growing urban demands. In addition, the method of making improper materials into the atmosphere that are harmful releases of CFCs [30]. Now, the task of managing the environment safely in conjunction with urban requirements is growing. Sustainability is involved here, which is necessary for managing resources to meet present and future needs and for choosing eco-sustainable materials to minimize greenhouse gas emissions into the interior air of buildings [65].

Hence, sustainable environment criteria should be considered while selecting construction materials. This observation shows that the environmental category is considered important in relation to the other categories in the Malaysian building industry.

In relation to the economic criteria, the results are as follows: $\mathrm{EC} 8>\mathrm{EC} 5>\mathrm{EC} 3>\mathrm{EC} 2>\mathrm{EC} 7>\mathrm{EC} 1>\mathrm{EC} 4>$ EC6. The life expectancy of materials, meeting stakeholders' needs, and operation and maintenance cost were ranked as the first, second, and third levels of importance. Moreover, the life expectancy of materials was ranked as the second important level among all criteria. Bashtannyk et al. [65] agreed that the economic criteria would impact the life cycle cost and maintenance to avoid materials replacement. The choice of appropriate green material for building on a site is an investment mode, as no maintenance costs are required during climate changes for materials [66]. On the other hand, the stakeholders need to consider that it is important to achieve their goal during materials selection. Mathiyazhagan et al. [8], it is a significant concern of materials to satisfy the users' needs. On the other hand, the life expectancy of material is nearly important to meet stakeholders' needs. Also, the durability of materials is indirectly enhancing the maintenance and life cycle cost [19].

Meanwhile, the results from the social category are as follows: $\mathrm{S} 4>\mathrm{S} 7>\mathrm{S} 8>\mathrm{S} 1>\mathrm{S} 12>\mathrm{S} 5>\mathrm{S} 9>\mathrm{S} 10>\mathrm{S} 6>$ $\mathrm{S} 3>\mathrm{S} 11>\mathrm{S} 2$. The health and safety creation takes the first level of importance and the third place among all criteria, followed by the use of local material and labor availability with the second and third level of importance. Fatimah et al. [62] mentioned that site safety improves social life by providing a clean and safe working environment. Furthermore, labor availability improves the construction work by enhancing the cost and time saving [10]. Nevertheless, using 
local materials is a criterion often considered associated with job creation due to a growing understanding of its consequences [19]. The consideration of social aspects during the selection of the materials provides a safer working environment. Therefore, the sustainability of building projects will be enhanced and improved.

From the results, it can be concluded that each respondent agreed that all criteria are critical by indicating that all mean scores were $>3$. However, each respondent had a different perception of each criterion's importance based on the standard deviation scores. Building projects greatly influence the economy, society, and the environment over their whole life cycle [3]. There is a need for strategies to have a strong view of the project's uptake situation and realize the many alternatives to achieve sustainability [67]. The GBMs criteria for selecting materials are recognized as being able to achieve sustainability for construction projects. The analysis identified all respondents agree on all criteria' positive influence for the GBMs selection by performing the scatter plot of mean and standard deviation scores. This demonstrates the importance of the sustainable criteria of the GBMs selection to stakeholders in the Malaysian building industry.

\section{Implementation of the Study}

The research offers a range of theoretical and practical applications at the academic and industry level. The implementation of building projects through the same mechanism as the inability to acknowledge reform could be part of the primary reason for the failure to make progress in the construction sector's performance within the nation of Malaysian. To overcome these issues, stakeholders must be able to adopt innovative new philosophies, particularly those specifically affecting the implementation of projects. Therefore, this study indicates no adoption of the GBMs criteria for material selection, the need to follow the GBM criteria for material selection in Malaysia's building industry. For this to happen, stakeholders must be informed, through lectures and workshops, of implementing new ideas that will enable projects to succeed. This action makes it easier to resolve the client's misapprehension of the GBMs requirements for material selection. Consequently, the perspectives obtained from this study would provide owners or employers with an appreciation of the key obstacles that impede the adaptation of the GBM criteria for material selection. Building practitioners must also be qualified in the philosophies, principles, and tools laid forth in the GBM guidelines to select materials procedures.

The respective building stakeholders' bodies in Malaysia should also hold regular training seminars for their participants on the GBM requirements for content selection. They should include the same in their ongoing appraisal of professional development. The government also plays a major role in the execution of public projects and creating and regulating regulations and policies across various sectors. The government will also encourage the GBM standards to procure materials used by creating regulations and legislation to facilitate its implementation in the country of projects in the building field. Building industry companies cannot enforce the GBM standards for content procurement at the business level.
Similarly, workers cannot be educated without senior management instruction. Appropriate enforcement processes for these measures must also be established to ensure compliance. Finally, by the proposed essential criteria created by this analysis, a standard for the project team in the Malaysia construction industry can be developed to manage the successful project by adopting GBM criteria to efficiently select materials.

\section{CONCLUSION}

Like many other developing countries, Malaysia has faced enormous difficulties in delivering high-quality housing infrastructure and carrying out large-scale construction programs. GBMs guidelines for content collection should be adopted to mitigate this situation. As a result, this is the primary goal of this research. Three main criteria and 32 subcriteria were identified based on the three sustainability pillars. Questionnaire surveys were distributed to various stakeholders in the Malaysian building industry to get the perceived value of the criteria and determine the relative importance of the GBMs criteria.

The results from the questionnaire survey through EFA analysis confirm GBM criteria' categorization under three sustainability pillars (environmental, economic, and social). An analysis of the ranking showed that all criteria to be relevant in the selection of building materials. A ranking analysis has been used to rank the GBMs criteria. The ranking analysis shows the significant criteria in the environmental cluster, which are waste management, water consumption, and potential for recycling and reuse. Meanwhile, material life expectancy, meeting stakeholders' needs, and operation and maintenance costs were ranked as the top three under the economic category. Also, health and safety, use of local material, and labor availability were ranked as the top three sub-criteria in the social category.

This study adds to the body of expertise in this area by providing essential inputs for researchers to enhance their interpretation of the GBMs criteria for selecting materials and lays a solid basis for future studies on the GBMs criteria for selecting materials. The results from this study would be helpful to improve sustainability studies and application within this country since it suffers from low environmental performance.

\section{REFERENCES}

[1] A. E. Oke, A. F. Kineber, I. Albukhari, I. Othman, and C. Kingsley, "Assessment of cloud computing success factors for sustainable construction industry: The case of Nigeria," Buildings, vol. 11, no. 2 , pp. 1-15, 2021, doi: 10.3390/buildings11020036.

[2] Y. H. Chiang, J. Li, L. Zhou, F. K. W. Wong, and P. T. I. Lam, "The nexus among employment opportunities, life-cycle costs, and carbon emissions: a case study of sustainable building maintenance in Hong Kong," J. Clean. Prod., vol. 109, pp. 326-335, 2015.

[3] A. T. W. Yu, A. A. Javed, T. I. Lam, G. Q. Shen, and M. Sun, "Integrating value management into sustainable construction projects in Hong Kong," Eng. Constr. Archit. Manag., 2018.

[4] M. U. Hossain and S. T. Ng, "Strategies for enhancing the accuracy of evaluation and sustainability performance of building," J. Environ. Manage., vol. 261, p. 110230, 2020.

[5] A. F. Kineber, I. Othman, A. E. Oke, N. Chileshe, and B. Alsolami, "Critical Value Management Activities in Building Projects: A Case of Egypt," Buildings, vol. 10, no. 12, p. 239, 2020.

[6] A. F. Kineber, I. Othman, A. E. Oke, N. Chileshe, and M. K. Buniya, "Identifying and assessing sustainable value management 
implementation activities in developing countries: The case of Egypt," Sustain., vol. 12, no. 21, pp. 1-20, 2020, doi: 10.3390/su12219143.

[7] R. K. Singh, H. R. Murty, S. K. Gupta, and A. K. Dikshit, "An overview of sustainability assessment methodologies," Ecol. Indic., vol. 9, no. 2, pp. 189-212, 2009 .

[8] K. Mathiyazhagan, A. Gnanavelbabu, and B. L. Prabhuraj, "A sustainable assessment model for material selection in construction industries perspective using hybrid MCDM approaches," $J$. Adv. Manag. Res., 2019.

[9] P. R. Kleindorfer, K. Singhal, and L. N. Van Wassenhove, "Sustainable operations management," Prod. Oper. Manag., vol. 14, no. 4, pp. 482-492, 2005.

[10] K. Govindan, K. M. Shankar, and D. Kannan, "Sustainable material selection for construction industry-A hybrid multi criteria decision making approach," Renew. Sustain. energy Rev., vol. 55, pp. 1274 1288,2016

[11] W. S. Lim and N. M. Suki, "Conceptual Study of Consumers' Intention to Purchase Sustainable Building in Malaysia," Int. J. Psychosoc. Rehabil., vol. 24, no. 2, 2020.

[12] E. Al-Atesh, Y. Rahmawati, and N. A. W. A. Zawawi, "Sustainability Criteria for Green Building Material Selection in the Malaysian Construction Industry," in Proceedings of the International Conference on Civil, Offshore and Environmental Engineering, 2021, pp. 693-700.

[13] I. Othman, Y. Y. Al-Ashmori, Y. Rahmawati, Y. H. M. Amran, and M. A. M. Al-Bared, "The level of Building Information Modelling (BIM) Implementation in Malaysia," Ain Shams Eng. J., 2020.

[14] N. Z. Abidin, "Investigating the awareness and application of sustainable construction concept by Malaysian developers," Habitat Int., vol. 34, no. 4, pp. 421-426, 2010

[15] Y. Chen, G. E. Okudan, and D. R. Riley, "Sustainable performance criteria for construction method selection in concrete buildings," Autom. Constr., vol. 19, no. 2, pp. 235-244, 2010.

[16] D. O. Aghimien, A. E. Oke, and C. O. Aigbavboa, "Barriers to the adoption of value management in developing countries," Eng. Constr. Archit. Manag., vol. 25, no. 7, pp. 818-834, 2018, doi: 10.1108/ECAM-04-2017-0070.

[17] M. K. Buniya, I. Othman, R. Y. Sunindijo, A. F. Kineber, E. Mussi, and H. Ahmad, "Barriers to safety program implementation in the construction industry," Ain Shams Eng. J., vol. 12, no. 1, pp. 65-72, 2021, doi: 10.1016/j.asej.2020.08.002.

[18] I. Othman, A. F. Kineber, A. E. Oke, T. Zayed, and M. K. Buniya, "Barriers of value management implementation for building projects in Egyptian construction industry," Ain Shams Eng. J., vol. 12, no. 1, pp. 21-30, 2021, doi: 10.1016/j.asej.2020.08.004.

[19] P. O. Akadiri and P. O. Olomolaiye, "Development of sustainable assessment criteria for building materials selection," Eng. Constr. Archit. Manag., 2012.

[20] L. E. Simão, M. B. Gonçalves, and C. M. T. Rodriguez, "An approach to assess logistics and ecological supply chain performance using postponement strategies," Ecol. Indic., vol. 63, pp. 398-408, 2016

[21] P. Pradhan, L. Costa, D. Rybski, W. Lucht, and J. P. Kropp, "A systematic study of Sustainable Development Goal (SDG) interactions," Earth's Futur., vol. 5, no. 11, pp. 1169-1179, 2017.

[22] M. Nilsson, D. Griggs, and M. Visbeck, "Policy: map the interactions between Sustainable Development Goals," Nature, vol. 534, no. 7607, pp. 320-322, 2016.

[23] T. Häkkinen, "Assessment of indicators for sustainable urban construction," Civ. Eng. Environ. Syst., vol. 24, no. 4, pp. 247-259, 2007.

[24] H. Zhang, Y. Peng, G. Tian, D. Wang, and P. Xie, "Green material selection for sustainability: A hybrid MCDM approach," PLoS One, vol. 12, no. 5, p. e0177578, 2017.

[25] S. M. Khoshnava, R. Rostami, A. Valipour, M. Ismail, and A. R. Rahmat, "Rank of green building material criteria based on the three pillars of sustainability using the hybrid multi criteria decision making method," J. Clean. Prod., vol. 173, pp. 82-99, 2018.

[26] A. Diabat, D. Kannan, and K. Mathiyazhagan, "Analysis of enablers for implementation of sustainable supply chain management-A textile case," J. Clean. Prod., vol. 83, pp. 391-403, 2014.

[27] A. Zhang, H. Li, and R. Peng, "The forecasting of $3 \mathrm{G}$ market in China based on a multi-generation model," in 2009 International Conference on Management and Service Science, 2009, pp. 1-3.

[28] Y. Li, "The Green Building Materials Enterprises in the Management of Innovation and Production Technology Improvement," in $L T L G B$ 2012, Springer, 2013, pp. 879-886.
[29] S. Beder, Environmental principles and policies: an interdisciplinary introduction. Routledge, 2013

[30] N. Sengupta, "Use of cost-effective construction technologies in India to mitigate climate change," Curr. Sci., pp. 38-43, 2008.

[31] R. Spiegel and D. Meadows, Green building materials: a guide to product selection and specification. John Wiley \& Sons, 2010.

[32] U. A. Umar, H. Tukur, M. Khamidi, and A. U. Alkali, "Impact of environmental assessment of green building materials on sustainable rating system," in Advanced Materials Research, 2013, vol. 689, pp. 398-402.

[33] L. C. Bank, B. P. Thompson, and M. McCarthy, "Decision-making tools for evaluating the impact of materials selection on the carbon footprint of buildings," Carbon Manag., vol. 2, no. 4, pp. 431-441, 2011

[34] M. Arif, D. Bendi, T. Toma-Sabbagh, and M. Sutrisna, "Construction waste management in India: an exploratory study," Constr. Innov., 2012

[35] H. Jain and S. Shrivastava, "Accounting of water footprint in substructure in a typical Multistory concrete building," 2016.

[36] J.-J. Wang, Y.-Y. Jing, C.-F. Zhang, and J.-H. Zhao, "Review on multi-criteria decision analysis aid in sustainable energy decisionmaking," Renew. Sustain. energy Rev., vol. 13, no. 9, pp. 2263-2278, 2009

[37] J. K. W. Wong and H. Li, "Application of the analytic hierarchy process (AHP) in multi-criteria analysis of the selection of intelligent building systems," Build. Environ., vol. 43, no. 1, pp. 108-125, 2008.

[38] M. Arif, M. Syal, L. Florez, D. Castro, and J. Irizarry, "Measuring sustainability perceptions of construction materials," Constr. Innov. 2013

[39] K. P. Ramaswamy and S. N. Kalidindi, "Waste in Indian building construction projects," 2009.

[40] M. F. Ashby and K. Johnson, Materials and design: the art and science of material selection in product design. ButterworthHeinemann, 2013

[41] K. R. Bunz, G. P. Henze, and D. K. Tiller, "Survey of sustainable building design practices in North America, Europe, and Asia," $J$. Archit. Eng., vol. 12, no. 1, pp. 33-62, 2006.

[42] M. Calkins, Materials for sustainable sites: a complete guide to the evaluation, selection, and use of sustainable construction materials. John Wiley \& Sons, 2008.

[43] I. Othman, A. F. Kineber, A. E. Oke, N. Khalil, and M. K. Buniya, "Drivers of Value Management Implementation in Building Projects in Developing Countries," J. Phys. Conf. Ser., vol. 1529, no. 4, 2020, doi: $10.1088 / 1742-6596 / 1529 / 4 / 042083$

[44] I. Othman, M. Kamil, R. Y. Sunindijo, M. Alnsour, and A. F. Kineber, "Critical success factors influencing construction safety program implementation in developing countries," J. Phys. Conf. Ser., vol. 1529, no. 4, 2020, doi: 10.1088/1742-6596/1529/4/042079.

[45] P. Bazeley, "The evolution of a project involving an integrated analysis of structured qualitative and quantitative data: From N3 to NVivo," Int. J. Soc. Res. Methodol., vol. 5, no. 3, pp. 229-243, 2002, doi: 10.1080/13645570210146285.

[46] M. Mason, "Sample size and saturation in $\mathrm{PhD}$ studies using qualitative interviews," in Forum qualitative Sozialforschung/Forum. qualitative social research, 2010, vol. 11, no. 3 .

[47] E. G. Ochieng and A. D. F. Price, "Managing cross-cultural communication in multicultural construction project teams: The case of Kenya and UK," Int. J. Proj. Manag., vol. 28, no. 5, pp. 449-460, 2010, doi: 10.1016/j.ijproman.2009.08.001.

[48] M. K. Buniya, I. Othman, S. Durdyev, R. Y. Sunindijo, S. Ismail, and A. F. Kineber, "Safety program elements in the construction industry: The case of Iraq," Int. J. Environ. Res. Public Health, vol. 18, no. 2 , pp. 1-13, 2021, doi: 10.3390/ijerph18020411.

[49] A. F. Kineber, I. Othman, A. E. Oke, N. Chileshe, and T. Zayed, "Prioritization of value management implementation critical success factors for sustainable residential building: A structural equation modelling approach," J. Clean. Prod., p. 126115, 2021.

[50] A. F. Kineber, I. Othman, A. E. Oke, N. Chileshe, and M. K. Buniya, "Impact of Value Management on Building Projects Success: Structural Equation Modeling Approach," J. Constr. Eng. Manag., vol. 147 , no. 4, p. 4021011, 2021.

[51] A. Akintoye and E. Fitzgerald, "A survey of current cost estimating practices in the UK," Constr. Manag. Econ., vol. 18, no. 2, pp. 161 $172,2000$.

[52] H. F. Kaiser, "An index of factorial simplicity," Psychometrika, vol 39, no. 1, pp. 31-36, 1974. 
[53] Y. Rahmawati, C. Utomo, and N. A. W. A. Zawawi, "BIM and ENegotiation Practices in AEC Consulting Businesses," Sustainability, vol. 11, no. 7, p. 1911, 2019.

[54] A. K. M. Shamseldin, "Including the building environmental efficiency in the environmental building rating systems," Ain Shams Eng. J., vol. 9, no. 4, pp. 455-468, 2018.

[55] S. Halliday, "Sustainable Construction Butterworth Heinemann." London, 2008.

[56] K. C. Goh and J. Yang, "Developing a life-cycle costing analysis model for sustainability enhancement in road infrastructure project," Rethink. Sustain. Dev. Planning, Infrastruct. Eng. Des. Manag. Urban Infrastruct., pp. 324-331, 2009.

[57] J.-T. S.-J. Lombera and J. C. Rojo, "Industrial building design stage based on a system approach to their environmental sustainability," Constr. Build. Mater., vol. 24, no. 4, pp. 438-447, 2010.

[58] M. A. Musarat, W. S. Alaloul, and M. S. Liew, "Impact of inflation rate on construction projects budget: A review," Ain Shams Eng. J., 2020 .

[59] M. Masri, R. M. Yunus, and S. S. Ahmad, "Underlying concerns of socio-cultural aspects in green building rating systems towards improving quality of life," Procedia-Social Behav. Sci., vol. 222, pp. 710-719, 2016

[60] A. C. P. Frijters and P. H. J. J. Swuste, "Safety assessment in design and preparation phase," Saf. Sci., vol. 46, no. 2, pp. 272-281, 2008.
[61] E. M. Singh and D. P. Singh, Violence: Impact and intervention. Atlantic Publishers \& Dist, 2008.

[62] Y. A. Fatimah, K. Govindan, R. Murniningsih, and A. Setiawan, "Industry 4.0 based sustainable circular economy approach for smart waste management system to achieve sustainable development goals: A case study of Indonesia," J. Clean. Prod., vol. 269, p. 122263, 2020.

[63] A. E. Krauklis, C. W. Karl, A. I. Gagani, and J. K. Jørgensen, "Composite Material Recycling Technology-State-of-the-Art and Sustainable Development for the 2020s," J. Compos. Sci., vol. 5, no. 1, p. 28,2021

[64] V. W. Y. Lam et al., "Climate change, tropical fisheries and prospects for sustainable development," Nat. Rev. Earth Environ., vol. 1, no. 9, pp. 440-454, 2020.

[65] V. Bashtannyk, Z. Buryk, M. Kokhan, T. Vlasenko, and V. Skryl, "Financial, economic and sustainable development of states within the conditions of industry 4.0," Int. J. Manag., vol. 11, no. 4, pp. 406-413, 2020 .

[66] M. Alamgir, M. J. Campbell, S. Sloan, J. Engert, J. Word, and W. F. Laurance, "Emerging challenges for sustainable development and forest conservation in Sarawak, Borneo," PLoS One, vol. 15, no. 3, p. e0229614, 2020.

[67] A. Maceika, A. Bugajev, and O. R. Šostak, "The modelling of roof installation projects using decision trees and the AHP method," Sustain., vol. 12, no. 1, pp. 1-21, 2020, doi: 10.3390/SU12010059. 